\title{
Effects of Playing with Gadget on Elementary School Children in Urban and Rural Environment
}

\author{
Ariani Ariani ${ }^{*}$, Ni Luh Putu $\mathrm{HM}^{2}$, Richi Aditya ${ }^{3}$, Novi Endriyani ${ }^{3}$ and Rusdian Niati ${ }^{3}$ \\ ${ }^{1}$ Department of Pediatrics, Medical Faculty, University of Brawijaya, Indonesia \\ Jalan Veteran, Ketawanggede, Kecamatan Lowokwaru, Ketawanggede, Kec. Lowokwaru, Kota \\ Malang, Jawa Timur 65145 \\ ${ }^{2}$ Midwifery Master's Degree Program, Medical Faculty, University of Brawijaya, Indonesia \\ Jalan Veteran, Ketawanggede, Kecamatan Lowokwaru, Ketawanggede, Kec. Lowokwaru, Kota \\ Malang, Jawa Timur 65145 \\ ${ }^{3}$ Residents of Department of Pediatrics, Medical Faculty, University of Brawijaya, Indonesia \\ Jalan Veteran, Ketawanggede, Kecamatan Lowokwaru, Ketawanggede, Kec. Lowokwaru, Kota \\ Malang, Jawa Timur 65145 \\ *Corresponding author: arianidr@yahoo.com
}

\begin{abstract}
Background: The existence of gadget is like the two sides of a coin. On one side, it brings benefits to our life, but on the other side, it facilitates negative behaviour impacts to its users, and the patterns for rural children may be different than those of urban. Objective: This study aimed to investigate the negative behaviour effect of playing gadget of elementary school children in urban and rural areas of Malang, Indonesia. Method: Information regarding characteristic of playing gadget and behaviour were collected via a self-administered questionnaire from Januari to June, 2017. This study included 355 subjects of urban and rural elementary school chidren aged 7-11 y.o in Malang, East Java, Indonesia. Result: A total of 100\% of subjects reported to be using gadgets, the mean ( $\pm S D)$ of age start using gadget was $2.63 \pm 0.548$ y.o Overall, $3.4 \%$ subjects had started using gadget in less than 2 y.0, 29.9\% subjects had started using gadget in 2 until 5 y.o, and $66.8 \%$ were more than 5 y.o. In addition, $13.5 \%$ of the subjects reported $>2$ hours/day of total gadgets usage duration, exceeding the international recommendation of $<2$ hours/day of screen time. The statistically data (logistic multinomial regression) show that earlier age using gadget especially watching movies had negative impact in behaviour $(p<0.000)$ than playing games. Conclusion: This suggests that, the trend of earlier using gadget which may contribute to negative behaviour, is found to be prevalent in urban $(26.3 \%)$ than rural areas $(13.6 \%)$. Both residence and age start using gadget statistically significant affect the child's negative behavior ( $p$ 0.040; $p<0.000$ ).
\end{abstract}

Keywords: urban, rural, behaviour, gadget, elementary school.

\section{INTRODUCTION}

The use of interactive screen media by young children is increasing rapidly. There are evidences that the amount of time children are spending on technological devices and social media at home and in school has raised concerns on the impact of these activities on their health and development (Roser, Schoeni, Foerster \& Röösli, 2016). According to a study, adolescents who spent increasing amounts of time using the computer or mobile phones were labeled as being "addicted to the Internet." This is found to interfere with the daily routine of one's life and is often associated with depression and stress also many other negative behaviour (Sjolie, \& Thuen, 2002). 
Physical environment has been an interest of public health research in the past decade. Numerous studies had been published regarding environmental attributes and their association with children's behaviour (Krizek, Birnbaum, \& Levinson) The urban area is defined as the region surrounding a city which is developed, meaning there is a density of human structures such as houses, commercial buildings, roads, bridges, etc. Rural area is a geographic area that is located outside towns and cities. Typical rural areas have a low population density and small settlements. Environmental association with behaviour and the use of gadget in adults is not applicable to children (Sjolie, \& Thuen, 2002). In contrast, children and adolescence represent unique parts of the life course that are particularly important in the development of lifelong behaviorural patterns.

Children nowadays start using gadgets in a very early age. They are exposed to digital devices since infancy. Video games may have just as much of a psychological effect as physical effect. A US based study indicated a strong relationship between adolescents who played a high number of video games, their aggressive behaviour with teachers and peers, and their poor performance in school. Exposure to violent games may have led to growth in negative behavior (Ferguson, 2015).

This study correlates the relationship of rural and urban environment, children's behavioural tendency and the use of gadget in children. Most children in urban and rural areas start using gadget in the first years of life but not all children develop the same behavioural tendency in the use of gadget.

\section{METHOD}

This was cross sectional study. We used questionnaire to collect the data. Children aged 7-12 years were recruited from primary schools from urban and rural areas using stratified random sampling. Subjects comprised boys and girls, from urban and rural areas in Malanf, East Java, Indonesia.

Questionnaire tools was divided into three parts: positive and negative behaviour, environments (family, school), and gadget recall. Participants were asked to give their answer by choosing one of the most suitable answer provided. Each answers were converted into score and then being calculated.

The correlation between variables were assessed using logistic regression test. Hosmer and Lemeshow Test were used to assess the goodness-of-fit of the data. Data was considered statistically significant if $p$ value $<0.05$.

\section{RESULT AND DISCUSSION}

Based on the questionnaire results, we applied Hosmer and Lemeshow Test to assess the goodness-of-fit of the data. Then we assess $\mathrm{R}$ square Nagelkerke to calculate the predictive power. Table 1 presents the socio-demographic profile of the study participants with mean age \pm 10.3 y.o. The mean $( \pm S D)$ of age start using gadget was $2.63 \pm 0.548$ y.o. Overall, 3.4\% subjects had started using gadget in less than 2 y.0, 29.9\% subjects had started using gadget in 2 until 5 y.o, and $66.8 \%$ were more than 5 y.o. In addition, $13.5 \%$ of the subjects reported $>2$ hours/day of total gadgets usage duration, exceeding the international recommendation of $<2$ hours/day of screen time. 
Table 1 Baseline Characteristics Of Participants

\begin{tabular}{|c|c|c|c|}
\hline Variables & Groups & n & $\%$ \\
\hline \multirow[t]{2}{*}{ Age in years } & $<10$ y.o & 154 & 44 \\
\hline & $>10$ y.o & 201 & 56 \\
\hline \multirow{2}{*}{ School Location } & Urban & 293 & 82 \\
\hline & Rural & 62 & 18 \\
\hline \multirow[t]{2}{*}{ Sex } & Male & 188 & 52 \\
\hline & Female & 167 & 48 \\
\hline \multirow[t]{3}{*}{ Duration using gadget } & $<1$ hour & 93 & 26,5 \\
\hline & $1-2$ hours & 214 & 60 \\
\hline & $>2$ hours & 48 & 13,5 \\
\hline \multirow{3}{*}{ Age start using gadget } & $<2$ y.o & 12 & 3.4 \\
\hline & $2-5$ y.o & 106 & 29.9 \\
\hline & $>5$ y.o & 237 & 66.8 \\
\hline
\end{tabular}

Environment and Behavioural Tendencies

The data in Table 2 shows that of all children who have a positive environment, as many as $65.1 \%$ have a tendency of negative behaviour. Of all the children with negative environments, only $34.9 \%$ experienced negative tendency behaviour. The correlation between environment and behaviour is statistically significant $(p=0.008)$.

Table 2 Correlation Between Environment And Behavioural Tendencies

\begin{tabular}{|c|c|c|c|c|c|}
\hline \multirow{6}{*}{$\begin{array}{c}\text { Behavioural } \\
\text { Tendency }\end{array}$} & & \multicolumn{2}{|c|}{ Environmental Tendency } & \multirow{2}{*}{ Total $(\%)$} & \multirow{2}{*}{$\begin{array}{c}p \\
\text { value }\end{array}$} \\
\hline & & Positive (\%) & Negative $(\%)$ & & \\
\hline & \multirow[t]{2}{*}{ Positive } & 214 & 55 & 269 & \multirow{4}{*}{0.008} \\
\hline & & $(79.3)$ & $(20.7)$ & $(100)$ & \\
\hline & \multirow[t]{2}{*}{ Negative } & 56 & 30 & 86 & \\
\hline & & $(65.1)$ & $(34.9)$ & $(100)$ & \\
\hline \multirow{2}{*}{ Total } & & 270 & 85 & 355 & \\
\hline & & $(75.8)$ & $(24.2)$ & $(100)$ & \\
\hline
\end{tabular}

\section{School Location and Behavioural Tendencies}

In Table 3, the children who attended elementary school in urban area, $90.7 \%$ had a negative behavioral tendency and of all the children in elementary school located in rural area, only $9.3 \%$ experienced negative behavioral tendencies. The result of analysis obtained which indicate that correlation between elementary school location and bbehaviorur is statistically significant $(p=0,037)$ and correlation value 0,110 show positive correlation.

Table 3 Correlation Between School Location And Behavioural Tendencies

\begin{tabular}{|c|c|c|c|c|c|c|}
\hline & \multirow{2}{*}{$\begin{array}{c}\text { Variable } \\
\text { s }\end{array}$} & \multicolumn{2}{|c|}{ School Location } & \multirow{2}{*}{$\begin{array}{c}\text { Total } \\
(\%)\end{array}$} & \multirow{2}{*}{$p$ value } & \multirow{2}{*}{$\begin{array}{c}\text { Correlation } \\
\text { value }\end{array}$} \\
\hline & & Urban Area(\%) & Rural area (\%) & & & \\
\hline \multirow{3}{*}{$\begin{array}{l}\text { Behavioural } \\
\text { Tendency }\end{array}$} & Positive & 219 & 51 & 270 & \multirow{3}{*}{0.037} & \multirow{3}{*}{0.110} \\
\hline & & $(81.1)$ & (18.9) & $(100)$ & & \\
\hline & Negative & $\begin{array}{c}77 \\
(90.7) \\
\end{array}$ & $\begin{array}{c}8 \\
(9.3) \\
\end{array}$ & $\begin{array}{c}85 \\
(100) \\
\end{array}$ & & \\
\hline Total & & $\begin{array}{c}296 \\
(83.4)\end{array}$ & $\begin{array}{c}59 \\
(16.6)\end{array}$ & $\begin{array}{c}355 \\
(100)\end{array}$ & & \\
\hline
\end{tabular}

The Relationship of Environment and Negative Behaviour based on Age Using Gadget 
According to Table 4, age using gadgets have a statistically significant effect on negative behaviour, while environmental variables have no statistically effects on negative behaviour. Children living in positive environments are 1.529 times less likely to behave negatively than children living in negative environments. Children who start using gadgets at $<2$ year are potentially to have negative behaviour 0.19 times compared to children who start using gadgets at age> 5 years. Children who start gadgets at 2-5 years of age have the potential to behave negatively 0.198 times compared to children who start using gadgets at age> 5years.

Table 4 Analysis Of Logistic Regression Of Relationship Between Environment And Negative Behaviour Based On Age Using Gadget

\begin{tabular}{|c|c|c|c|c|}
\hline \multicolumn{2}{|c|}{ Variables } & \multirow{2}{*}{$\begin{array}{c}\text { OR } \\
1.529\end{array}$} & \multirow{2}{*}{$\begin{array}{c}\mathbf{9 5 \%} \mathrm{CI} \\
0.854-2.738\end{array}$} & \multirow{2}{*}{$\begin{array}{r}\text { p value } \\
0.008\end{array}$} \\
\hline Behavioural Tendency & $\begin{array}{l}\text { Positive } \\
\text { Negative }\end{array}$ & & & \\
\hline \multirow{3}{*}{ Age using Gadget } & $<2$ y.o & 0.190 & $0.056-0.645$ & \multirow{3}{*}{0.000} \\
\hline & $2-5$ y.o & 0.198 & $0.116-0.339$ & \\
\hline & $>5 \mathrm{y} .0$ & 0.190 & $0.055-0.544$ & \\
\hline
\end{tabular}

The Relationship of Environmental Influence and Negative Behavior Based on the Duration of Using Gadget

In Table 5, all the variables have a statistically significant effect on negative behavior. The data shown below is the estimate parameter table. Children living in positive environments are 2.23 times less likely to behave negatively than children living in negative environments. Children who play gadgets for $<1$ hour/day potentially behave negatively 0.337 times compared to children who start using gadgets for $>2$ hours /day, but the difference between playing gadget length is not statistically significant with $\mathrm{p}>0.05$. Children who play the gadget for 1-2 hours/day potentially have negative behavior 0.112 times compared to children who started using the gadget for $>2$ hours / day.

Table 5 Analysis Of Logistic Regression Between Environmental Influence And Negative Behaviour Based On The Duration Of Using Gadget

\begin{tabular}{|c|c|c|c|c|c|c|}
\hline \multicolumn{2}{|c|}{ Variables } & \multicolumn{2}{|c|}{$\begin{array}{c}\text { Environment } \\
\text { n }(\%)\end{array}$} & \multirow[t]{2}{*}{ OR } & \multirow[t]{2}{*}{$95 \% \mathrm{CI}$} & \multirow{2}{*}{$\begin{array}{c}\mathbf{P} \\
\text { Value }\end{array}$} \\
\hline & & Positive & Negative & & & \\
\hline \multirow{5}{*}{$\begin{array}{c}\text { Behavioural } \\
\text { Tendency }\end{array}$} & Positive & $214(79.3)$ & $55(20.7)$ & \multirow{2}{*}{2.23} & $1.269-3.919$ & \multirow{2}{*}{0 . } \\
\hline & Negative & $56(65.1)$ & 30 (34.9) & & & \\
\hline & $<1$ hour & & & 0.337 & $0.092-1.233$ & 0.100 \\
\hline & 1-2 hours & & & 0.112 & $0.033-0.380$ & 0.000 \\
\hline & $>2$ hours & & & & & \\
\hline
\end{tabular}

The Relationship of Environment and Negative Behavior based on Game Types

There is statistically significant effect of type of gadget game to the negative behaviorur. Children living in positive environments are 1.604 times less likely to behave negatively than children living in negative environments. Children who watched movies have the most potentially negative behaviour (OR 9,947). 
Table 6 The Relationship Of Environment And Negative Behaviour Based On Games Types

\begin{tabular}{|c|c|c|c|c|c|c|}
\hline \multicolumn{2}{|c|}{ Variables } & \multicolumn{2}{|c|}{$\begin{array}{l}\text { Environment } \\
\text { n }(\%)\end{array}$} & \multirow[t]{2}{*}{ OR } & \multirow[t]{2}{*}{$95 \% \mathrm{CI}$} & \multirow[t]{2}{*}{$\begin{array}{c}\mathbf{P} \\
\text { Value }\end{array}$} \\
\hline & & Positive & Negative & & & \\
\hline \multirow{2}{*}{$\begin{array}{c}\text { Behavioural } \\
\text { Tendency }\end{array}$} & Positive & $214(79.3)$ & $55(20.7)$ & 1.604 & $0.892-2.884$ & 0.115 \\
\hline & Negative & $56(65.1)$ & $30(34.9)$ & & & . \\
\hline \multirow{7}{*}{$\begin{array}{c}\text { Types of Gadget } \\
\text { Game }\end{array}$} & Puzzle & & & 0.455 & $0.217-0.950$ & 0.036 \\
\hline & War / Battle & & & 0.516 & $0.218-1.220$ & 0.132 \\
\hline & Soccer & & & 2.449 & $0.298-20.131$ & 0.405 \\
\hline & Music & & & 1.895 & $0.408-8.796$ & 0.415 \\
\hline & Youtube & & & 8.762 & $8.762-8.762$ & . \\
\hline & Movies & & & 9.947 & 0.000 & 0.038 \\
\hline & Others & & & 5.492 & $0.714-42.220$ & 0.102 \\
\hline
\end{tabular}

In our study, all of children $(100 \%)$ in urban and rural use the gadget in their daily living for two hours or more. From the results of this study concluded that the urban environment has a tendency bad influence on children than in rural areas. Nowadays, naturerelated activities were less common in elementary school children (Master, Kaur, Narasimhan, Nadeem, Ali, \& Shaik. 2016); Loucaides, C.A., Chedzoy, S.M. \& Bennett, N, 2004). Children who lives in rural area experienced more actvities than those who lives in urban areas. Children who lives in positive environment have tendencies to behave negative behaviour (Loucaides et al., 2004; David-Ferdon, \& Hertz. 2007)). The study prove that negative behaviour can occur when the children exposed gadget too early in their lives, especially when they watch movies rather than playing games. This may be due to negative impact of the content of movies that the children still cannot distinguish which is good and right, they tend to watch alone without a parental assistance.

\section{CONCLUSION}

There was significant differences between urban and rural area in affecting children behaviour and the use of gadget. Urban area and age onset using gadget had more tendencies to cause children to have negative behaviour and misuse of gadget. Watching movies is more dangerous than playing games and other games. Residental environment is very influential on the formation of child behavior. Further studies were needed as there are many other environmental attributes which could affect behaviour and the use of gadget, especially in children.

\section{ACKNOWLEDGEMENT}

This research received no specific grant from any funding agency in the public, commercial, or not-for-profit sectors.

\section{REFERENCES}

American Academy of Pediatrics. (2013). Policy statement: children, adolescents, and the media." Pediatrics: 132(5):pp. 958-961. 
Badri, M., Alnuaimi, A., Al Rashedi, A., Yang, G., \& Temsah, K. (2016). School children's use of digital devices, social media and parental knowledge and involvement-the case of Abu Dhabi. Education and Information Technologies. p.1-20.

Brown, A. (2011). Media use by children younger than 2 years. Pediatrics. vol.128(5), pp.1040-1045.

Christakis, D.A. (2014). Interactive media use at younger than the age of 2 years: time to rethink the American Academy of Pediatrics guideline. JAMA Pediatr. vol.168(5): $\mathrm{p}$ 399-400.

David-Ferdon, C., \& Hertz, M.F. (2007). Electronic media, violence, and adolescents: an emerging public health problem. J Adolesc Health. Vol.41(6 Suppl 1): pp.1-5.

Ferguson, Christopher J. (2015). Do angry birds make for angry children? A meta-analysis of video game influences on children's and adolescents' aggression, mental health, prosocial behaviour, and academic performance. Perspectives on Psychological Science vol.10.5 : p 646-666.

Goh, W., Bay, S., \& Chen, V. (2015). Young school children's use of digital devices and parental rules. Telematics and Informatics, vol. 32: 787-795.

Krizek, K.J., Birnbaum, A.S. \& Levinson, D.M. A Schematic for Focusing on Youth in Investigations of Community Design and Physical Activity. The Science of Health Promotion. vol. 19: 1, p. 33-38.

Livingstone S. (2012). Children's use of mobile phones - an international comparison. Japan: The GSM Association, Mobile Society Research Institute, NTT DOCOMO Inc.

Loucaides, C.A., Chedzoy, S.M. \& Bennett, N. (2004). Differences in physical activity levels between urban and rural school children in Cyprus. Health Education Research Theory \& Practice, vol. 19 no. 2, pp. 138-147.

Master, M.K., Kaur, C.P., Narasimhan, A, Nadeem, M., Ali, M., \& Shaik, R.B., (2016). Impact of electronic gadgets on psychological behaviour of middle school children in UAE. Gulf Medical Journal.vol. 5(S2): p.54-60.

Radesky, J.S., Schumacher, J., \& Zuckerman, B. (2015). Mobile and interactive media use by young children: the good, the bad, and the unknown. Pediatrics: 135(1).

Roseberry, S., Hirsh-Pasek, K., \& Golinkoff, R.M. (2014). Skype me, Socially contingent interactions help toddlers learn language. Child Dev, vol. 85(3):956-970.

Roser K., Schoeni A., Foerster M. \& Röösli M. (2016). Problematic mobile phone use of Swiss adolescents: is it linked with mental health or behaviour?". Int J Public Health. Vol. 61(3):307-315.

Sjolie, A.N. \& Thuen, F. (2002). School journeys and leisure activities in rural and urban adolescents in Norway. Health Promotion International, vol. 17 no. 1, p. 21-30.

Wartella, E., Rideout, V., Lauricella, A.R. \& Connell, S.L. (2013). Parenting in the age of digital technology: a national survey. Center on Media and Human Development, School of Communication, Northwestern University. June.

Yoo, Y.S., Cho O.H., \& Cha K.S. (2014). Associations between overuse of the internet and mental health in adolescents. Nurs. Health Sci, vol.16(2): p 193-200,. 